\title{
Effects of improved fish production technology on the output of fish farmers in Ilorin, Kwara State, Nigeria
}

\author{
J.A. Akangbe, G.E. Ajiboye, and S.E. Komolafe* \\ Department of Agricultural Extension and Rural Development, University of Ilorin, Nigeria \\ *Correspondence: kemmas04@yahoo.com \\ Received: $30^{\text {th }}$ September 2015, Revised: $18^{\text {th }}$ December 2015, Accepted: $21^{\text {st }}$ December 2015
}

\begin{abstract}
The study examined the effects of improved fish production technology on the output of fish farmers in Ilorin Kwara State, Nigeria. A total of 125 respondents were selected. Primary data was collected with the use of structured questionnaire. Both descriptive and inferential statistics were employed for the study. Mean age of respondents was 39.8 years. Also majority were male $(83.2 \%)$, had tertiary education $(84.0 \%)$ and kept Catfish (90.4\%). The mean income earned was $\mathrm{N}$ 1,012,320.00. Commonly used/ adopted improved fish technologies were floating feeds $(84.8 \%)$, standard feeding regimes $(84.0 \%)$, improved breeds of fingerlings $(80.0 \%)$ and provision of inlet and outlet devices in pond (78.4). Farmers' perceptions were that the use of improved fish production technology saves time (mean=1.34), increases profit/improved income (mean=1.12) and conserves fish farmers' energy (mean=1.08). This study found average increase in output: input ratio as $0.77 \mathrm{~kg}$ of harvest per fish fingerlings stocked due to improved fish technology when compared to that before adoption of improved technology. Most indicated constraints faced by fish farmers were inadequate capital (88.0\%), high cost of feed (79.2\%) and high cost of fingerlings $(71.2 \%)$. Profit increase/improved income of catfish farmers via higher yield/harvest due to adoption of new technology was found to be positively correlated with age $(p<0.01)$, gender $(p<0.05)$, and experience $(\mathrm{p}<0.05)$. The study concluded that the use of fish improved technology had positively influenced harvest of catfish farmers in the study area. The study recommend the need for training, workshops and seminars for catfish farmers on how they could have easy access to land, feeds at affordable rate and sources of fund at minimal interest rate.
\end{abstract}

Keywords. Catfish farmers, fish production, improved technology, socio-economics. 


\section{Introduction}

Aquaculture is the breeding and rearing of fish, shellfish, or plants in ponds, or any enclosure for direct harvest of the product, which is an area of activity growing rapidly (FAO, 2004). Fish is acclaimed to be the principal source of animal protein for over one billion people globally as it is the cheapest source of animal protein, providing many important nutritional and health benefits (FAO, 2006).

In Nigeria, fish demand as estimated by Ruma (2008) was 2.1 million metric tons at $11.5 \mathrm{~kg}$ per capita consumption. The poor performance of the fishery sub sector in Nigeria is most clearly evidenced by low standard of living of the small scale rural fish farmers (FAO, 2006). To revamp this sub sector, government of Nigeria has introduced and implemented numerous policies and programmes aimed at empowering the small scale fish farmers to get out of the 'poverty trap'. This include, dissemination of improved catfish production technology such as adequate pond construction, water management, adequate stocking rate, use of nutritious and floating feed, and improved fish feed to the farmers (Ike et al., 2009). Ekong (2003) defined technology as ways of applying scientific and organized knowledge into practical task. In view of this, Lakra and Ayyappan (2003) had noted that increased application of advance technological tools could certainly revolutionise fish farming. Dissemination of proven technologies is a communication process of sharing and distributing information to a target audience to bridge the gap in knowledge and bring about changes in attitude and skill of the end users. Despite the efforts of government in research and extension services, there is still a deficit in the supply and demand for fish (FDF, 2005). Other problems facing domestic fish production in Nigeria are, innovation adoption, inadequate research and extension, high cost of fisheries inputs, preservation and storage technologies, fish seed, lack of credit and insurance cover for fisheries enterprises (Olaoye 2010).

Despite the fact that fish farming account for the highest percentage of the Nigerian's annual fish production output (FDF, 2005), fish workers are often among the poorest people and they generally operate small scale fishing units using traditional fishing practices. However, new technology and environmental requirements favour large scale capital intensive operation at the expense of traditional and small scale commercial fishing (Delgado et al, 2003). Thus, it is of paramount importance to study the effect of improved production technologies on the yields and income of fish farmers.

The main objective of the study is to examine the effects of improved fish production technology on the output of fish farmers in Ilorin Kwara State, Nigeria. The specific objectives of the study are to:

i. describe the socio-economic characteristics of fish farmers in the study area, 
ii. identify sources of information and types of fish production technology used by fish farmers,

iii. examine fish farmers perception and constraints faced to improve fish production technology.

The study aimed at testing the following null hypothesis $\left(\mathrm{H}_{0}\right)$ : there is no significant relationship between socio-economic characteristics of fish farmers and the effects of improved fish production technology.

\section{Materials and Methods}

\subsection{Study area}

The study was carried out in Ilorin, Kwara State Nigeria. Ilorin is the capital of Kwara State. The state is geographically located between latitude $7^{\circ} 20^{\prime}$ and $11^{\circ} 05^{\prime}$ north of the equator longitude $2^{\circ} 05^{\prime}$ and $6^{\circ} 45^{\prime}$ east of the prime meridian. The state is bounded in the North by Sokoto and Niger states, and the Federal Capital Territory, and in the South by Oyo, Osun, Ekiti and Edo States. The western boundary is Republic of Benin, while the eastern boundary consists of Plateau and Benue states. Kwara state has a population of 1.57 million and a land area of about $32,500 \mathrm{~km}^{2}$ with three main ethnic groups; Yoruba, Nupe and Baruba. The climate is intermediate, varying between the extremes of dryness, coolness and hotness. The mean monthly rainfall ranges between $50 \mathrm{~mm}$ during the wettest months and $24 \mathrm{~mm}$ during the driest period. The driest months are from January to March, while the rains last from May to September with occasional drizzles in October. The minimum average temperature throughout the state ranges between $21^{\circ} \mathrm{C}$ while maximum average temperature ranges approximately between $30^{\circ} \mathrm{C}$ and $35^{\circ} \mathrm{C}$ (KWADP 2000).

\subsection{Sampling procedure and sample size}

The population for this study comprised of all the 163 member of the Cat Fish Farmers Association of Nigeria (CAFFAN) and 247 member of the Association of Fish Farmers Association of Nigeria (AFFAN) in Ilorin Kwara State, Nigeria. Forty percent of the population from the two fish farmer associations were randomly selected. A total of 165 respondents were selected for the study. 


\subsection{Instrument for data collection}

The data collected for this study were obtained from primary and secondary sources. Primary data was collected from the field survey through the administration of structured questionnaire which was used to solicit information from the respondents on issues related to objectives of the study. The validity of the questionnaire was ensured by lecturers of the Department of Agricultural Extension and Rural Development, University of Ilorin. Secondary data on the other hand were collected from relevant literature, textbooks etc.

\subsection{Data analysis}

Of the 165 questionnaires administered, 130 were retrieved and 5 were rejected for incompleteness. A total of 125 questionnaires were therefore available for analysis. Data obtained from the field were subjected to descriptive and inferential statistics. The descriptive statistics tools used were frequency counts, percentage, mean score and standard deviation. Pearson Product Moment Correlation analysis was used to test the null hypothesis of the study.

\section{Results and Discussion}

\subsection{Socio-economic characteristics of respondents}

Results presented in Table 1 illustrate the socio-economic characteristics of fish farmers in Ilorin Kwara State, Nigeria. The results showed that the mean age of respondents was 39.8 years. The implication is that the fish farmers in the study area are fairly young, and are expected to be active in fisheries activities, and constitute potential labour force for the fisheries enterprise in the study area. The mean age of farmers in Nigeria is usually between 45-48 years (Ogunwale 2000; Ezedinma and Otti 2001). The reason for this particular age composition could be attributed to the fact that aquaculture is relatively new in the country. However, the result contradicts the findings of Ofuoku et al. (2008) that very few young people are involved in fish farming from a study in Dalta State of Nigeria.

As revealed by Table 1, the majority (83.2\%) of the farmers were male while only $16.8 \%$ was female. This implies that fish farming business is male dominated in the study area. This may be due to the high degree of human energy and physical exertion associated with farming activities, as it is evident from significantly low frequency of involvement of women in fish farming.

Table 1. Socio-economic characteristics of fish farmers in Ilorin (source: field survey, 2015). 


\begin{tabular}{|c|c|c|c|}
\hline Variables & Frequency $^{\mathrm{a}}$ & Percentage $^{b}$ & Mean \\
\hline \multicolumn{4}{|l|}{ Age (years) } \\
\hline Less than 30 & 38 & 30.4 & 39.8 \\
\hline $31-40$ & 43 & 34.4 & \\
\hline $41-50$ & 18 & 14.4 & \\
\hline $51-60$ & 12 & 9.6 & \\
\hline 61 and above & 14 & 11.2 & \\
\hline \multicolumn{4}{|l|}{ Gender } \\
\hline Male & 104 & 83.2 & \\
\hline Female & 21 & 16.8 & \\
\hline \multicolumn{4}{|l|}{ Marital Status } \\
\hline Single & 45 & 36.0 & \\
\hline Married & 78 & 62.4 & \\
\hline Widow/ Widower & 2 & 1.6 & \\
\hline Divorced & 0 & 0.0 & \\
\hline \multicolumn{4}{|l|}{ Educational Status } \\
\hline No formal education & 1 & 0.8 & \\
\hline Adult education & 3 & 2.4 & \\
\hline Primary education & 4 & 3.2 & \\
\hline Secondary education & 12 & 9.6 & \\
\hline Tertiary education & 105 & 84.0 & \\
\hline \multicolumn{4}{|c|}{ Fish farming experience (years) } \\
\hline $1-5$ & 79 & 63.2 & 6.5 \\
\hline $6-10$ & 22 & 17.6 & \\
\hline $11-15$ & 16 & 12.8 & \\
\hline $16-20$ & 6 & 4.8 & \\
\hline 21 and above & 2 & 1.6 & \\
\hline \multicolumn{4}{|c|}{ Fish farm size (No. of fingerlings) } \\
\hline Less than 1000 & 3 & 2.4 & 4,008 \\
\hline $1000-5,000$ & 108 & 86.4 & \\
\hline $5,001-10,000$ & 8 & 6.4 & \\
\hline 10,001 and above & 6 & 4.8 & \\
\hline \multicolumn{4}{|l|}{ Income per annum (Naira) } \\
\hline 200,000 and below & 23 & 18.4 & $1,012,320$ \\
\hline $201,000-400,000$ & 14 & 11.2 & \\
\hline $401,000-600,000$ & 16 & 12.8 & \\
\hline $601,000-800,000$ & 14 & 11.2 & \\
\hline $801,000-100,000$ & 18 & 14.4 & \\
\hline $1,000,000-2,000,000$ & 32 & 25.6 & \\
\hline $2,001,000$ and above & 8 & 6.4 & \\
\hline \multicolumn{4}{|c|}{ Extension Visit (per annum) } \\
\hline No visit & 73 & 58.4 & 1.75 \\
\hline $1-5$ & 40 & 32.0 & \\
\hline $6-10$ & 10 & 8.0 & \\
\hline $11-15$ & 2 & 1.6 & \\
\hline \multicolumn{4}{|c|}{$\begin{array}{l}\text { Number of Fish training/ seminar } \\
\text { attended }\end{array}$} \\
\hline No attendance & 29 & 23.2 & 3.0 \\
\hline $1-5$ & 17 & 57.6 & \\
\hline $6-10$ & 22 & 17.6 & \\
\hline $11-15$ & 2 & 1.6 & \\
\hline \multicolumn{4}{|l|}{ Type of fish kept } \\
\hline Catfish & 113 & 90.4 & \\
\hline Cat and Tilapia & 12 & 9.6 & \\
\hline
\end{tabular}

${ }^{\mathrm{a}}$ Total number of fish farmers under survey is 125 for all variables. 
Similar results of higher percentage of male involvement in fish farming were reported by Abiona et al. (2012). This is in consistence with the result of Chioma and Adebayo (2012) that although women in Ilorin have shown willingness to participate in fish farming, but are yet to involve in commercial fish farming and invest in it due to lack of funds.

As regards the marital status of respondents, the majority (62.4\%) was married. This shows that most of the fish farmers are men and women with household responsibilities. These responsibilities are likely to make them willing to seek innovations so as to increase their income earning capacity and improve their standard of living (Raufu et al., 2009). This ascertain was further confirmed by the report of Oladoja et al. (2008) who assert that marriage confer some level of responsibility and commitment on an individual who is married.

Information furnished in Table 1 also revealed that the majority (84.0\%) had attended tertiary education. This implies that fish farmers in the study area are educated and could be trusted to adopt any innovation that could enhance fish farming practices. Okunlola (2010) stated that educational level is one of the factors that influence adoption of new technology by farmers. Results of this study are consistent with previous studies by Adefalu et al. (2013) and Ofuoku et al. (2008) who reported a high percentage of fish farmers having tertiary education in Kwara State and Delta State respectively.

The majority (63.2\%) of respondents, being young fish farmers, had between 1-5 years in fish farming experience. The mean fish farming experience of respondents was 6.49 years. The mean score of fish farm size was 4,008 fingerlings. The mean annual income earned by respondents was estimated at Naira 1,012,320.

The annual mean number of extension visits to fish farmers in the study area was 1.75 , which was very low considering their importance for frequent update of improved technologies in enhancing fish production in the study area. Low involvement of extension workers could be as a result of the research institutes and extension organizations inadequate planning in Nigeria (Oladele, et al., 2006). Fasakin (2008) also stated that poor agricultural extension services are a serious constraint to fish production in Nigeria.

Of the 125 respondents, mean number of participants in training/seminars for fish farming was 2.99. Majority of fish farmers (90.4\%) kept catfish while others stocked both catfish and tilapia. This implies that catfish farming was predominant in the study area. In his studies in Cross River State, Ideba et al. (2013) too reported that the majority of fish farmers stocked Clarias (Catfish). 


\subsection{Types of improved fish technology used by respondents}

Table 2 presents information on the types of improved fish farming technology used by respondents, ranked in ascending order of the percentage of respondents using such technology. The results revealed that $84.8 \%$ used Floating feeds $(84.8 \%)$ was the top rank; followed by standard feeding regimes $(84.0 \%)$, improved breeds of fingerlings $(80.0 \%)$, provision of inlet and outlet devices in pond and frequent change of water $(78.4 \%)$, etc. The lowest ranks were soil testing before site selection (40.8\%), use of water testing kits $(34.4 \%)$ and construction of modern fishing gears $(32.8 \%)$.

Table 2. Types of improved fish technology used by respondents

\begin{tabular}{|c|c|c|c|}
\hline Improved fish technology used & Frequency* & Percentage & $\begin{array}{l}\text { Percentage } \\
\text { Rank }\end{array}$ \\
\hline Floating feeds & 106 & 84.8 & 1 \\
\hline Standard feeding regimes & 105 & 84.0 & 2 \\
\hline Improved breeds of fingerlings & 100 & 80.0 & 3 \\
\hline Provision of inlet and outlet devices in pond & 98 & 78.4 & 4 \\
\hline Frequent change of water & 98 & 78.4 & 4 \\
\hline Regular sampling/sorting of fish & 97 & 77.6 & 6 \\
\hline Daily sanitation and record-keeping practices & 87 & 69.6 & 7 \\
\hline Prevention and control of fish diseases & 86 & 68.8 & 8 \\
\hline Optimum stocking rate & 83 & 66.4 & 9 \\
\hline $\begin{array}{l}\text { Improved techniques in pond construction and } \\
\text { maintenance }\end{array}$ & 74 & 59.2 & 10 \\
\hline Fertilization and liming of fish pond & 70 & 56.0 & 11 \\
\hline Techniques of hatchery and fingerling production & 64 & 51.2 & 12 \\
\hline Fish preservation and storage techniques & 60 & 48.0 & 13 \\
\hline $\begin{array}{l}\text { Techniques of improving water quality in fish } \\
\text { culture }\end{array}$ & 57 & 45.6 & 14 \\
\hline $\begin{array}{l}\text { Integrated fish farming for increased fish } \\
\text { production }\end{array}$ & 57 & 45.6 & 14 \\
\hline $\begin{array}{l}\text { Aerated containers for transporting fingerlings to } \\
\text { reduce stress and mortality }\end{array}$ & 55 & 44.0 & 16 \\
\hline Soil testing before site selection & 51 & 40.8 & 17 \\
\hline Water testing kits for oxygen, acidity and fertility & 43 & 34.4 & 18 \\
\hline Construction of modern fishing gears & 41 & 32.8 & 19 \\
\hline
\end{tabular}

* multiple responses

\subsection{Sources of information on improved fish production technology}

Of the major source of information on improved fish production technology for fish farmers (Table 3) was information obtained from their fellow fish farmers (92.0\%). This finding is consistent with Ofuoku et al. (2008) and Okunlola et al. (2011) that the most popular sources of information available to fish farmers in Nigeria was interaction with other fish farmers. Also, the second important source of information (54.4\%) was from cooperative meetings. 
Table 3. Sources of information on improved fish production technology

\begin{tabular}{lcc}
\hline Information Sources & Frequency* & Percentage \\
\hline Agricultural Extension agent & 68 & 37.6 \\
Internet & 65 & 52.0 \\
Television & 35 & 28.0 \\
Radio & 27 & 21.6 \\
Print media & 40 & 32.0 \\
Cooperative meetings & 47 & 54.4 \\
Private consultants & 58 & 46.4 \\
Input dealers & 40 & 32.0 \\
Fellow fish farmers & 115 & 92.0 \\
\hline multiple responses & &
\end{tabular}

\subsection{Perception to use and effects of improved fish production technology}

Perception of farmers on improved fish production technology (Table 4) determined by Likert scale revealed that statement that use of improved fisheries technology saves time had the highest mean score of 1.34 .

Table 4. Perception to use and effects of improved fish production technology

\begin{tabular}{lccc}
\hline Perception Statements & $\begin{array}{c}{ }^{\mathrm{a}} \text { Mean } \\
\text { Score }\end{array}$ & $\begin{array}{c}\text { Std. } \\
\text { Dev. }\end{array}$ & $\begin{array}{c}\text { Mean } \\
\text { Rank }\end{array}$ \\
\hline $\begin{array}{l}\text { Using improved fisheries technologies saves time } \\
\text { Fish farmers' uses of improved technologies increases } \\
\quad \text { profit/improved income via higher yield/harvest }\end{array}$ & $1.34^{*}$ & 0.975 & 1 \\
$\begin{array}{l}\text { Improved fisheries technologies conserves fish farmers } \\
\quad \text { energy - Human, material \& finance }\end{array}$ & $1.08^{*}$ & 0.912 & 2 \\
$\begin{array}{l}\text { The require regular contact with extension workers } \\
\text { Improved technologies are only for the educated }\end{array}$ & $1.02^{*}$ & 1.020 & 3 \\
$\begin{array}{l}\text { They are not culturally suitable } \\
\text { Have high labour requirement }\end{array}$ & 0.97 & 1.150 & 5 \\
$\begin{array}{l}\text { Large family size dis-encourages fish farmers' use of } \\
\quad \text { improved technologies. }\end{array}$ & 0.82 & 1.001 & 6 \\
$\begin{array}{l}\text { Improve technologies are too complex for my linking } \\
\text { Lazy fish farmers use improved technologies }\end{array}$ & 0.72 & 1.052 & 7 \\
$\begin{array}{l}\text { Using improved fisheries technologies lead to high } \\
\text { product losses. }\end{array}$ & -0.15 & 1.115 & 10 \\
\hline
\end{tabular}

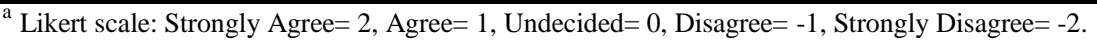

1-11 implies highest to lowest rank;

* high level of perception

Decision rule: Score mean 0.99 and below indicates Low level of perception; score mean between 1.00 and

2.00 indicates high level of perception. 
The second highest perception that use of improved technology increases profit/improved income via higher yield/harvest (mean score: 1.12), that the improved fisheries technology conserve fish farmers labour, material and finance (mean score: 1.08), and that the requirement for regular contact with extension workers (mean score: 1.02).

\subsection{Effects of improved fish production technology on farmers output}

The difference in stocking (input) and output (harvest) before and after the use of improved fish technology (Table 5) shows that the mean number of fingerlings stocked before improved fish technology was 835.6 and the mean output (harvest) without improved technology was $692.5 \mathrm{~kg}$. Hence, the output: input ratio before application of improved technology was $0.83 \mathrm{~kg}$ per fish fingerling.

Table 5. Fish production stock (number of fish) and output (Kg weight) with and without improved technology (Source: field survey, 2015)

\begin{tabular}{|c|c|c|c|c|}
\hline & $\begin{array}{c}\text { Stock } \\
* \text { Frequency }(\%)\end{array}$ & $\begin{array}{l}\text { Mean stock } \\
\text { input } \\
\text { (number of } \\
\text { fish) }\end{array}$ & $\begin{array}{c}\text { Output }(\mathrm{Kg}) \\
\text { *Frequency }(\%)\end{array}$ & $\begin{array}{l}\text { Mean output } \\
(\mathrm{Kg})\end{array}$ \\
\hline \multicolumn{2}{|c|}{ Before improved technologies } & 835.60 & & 692.53 \\
\hline Not Applicable & $61(48.8)$ & & $0(0.00)$ & \\
\hline $1-1000$ & $35(28.0)$ & & $40(32.0)$ & \\
\hline $1001-2000$ & $17(13.6)$ & & $16(12.8)$ & \\
\hline$>2000$ & $12(9.6)$ & & $8(6.4)$ & \\
\hline Total & $125(100.0)$ & & $64(51.2)$ & \\
\hline \multicolumn{2}{|c|}{ After improved technologies } & 3644.72 & & 5828.00 \\
\hline $1-2,000$ & $61(48.8)$ & & $36(28.8)$ & \\
\hline $2,001-4,000$ & $42(33.6)$ & & $35(28.0)$ & \\
\hline $4,001-8,000$ & $12(9.6)$ & & $37(29.6)$ & \\
\hline $8,001-10,000$ & $2(1.6)$ & & $4(3.2)$ & \\
\hline $10,001-12,000$ & $2(1.6)$ & & $2(1.6)$ & \\
\hline$>12,000$ & $6(4.8)$ & & 11(8.8) & \\
\hline Total & $125(100.0)$ & & $125(100.0)$ & \\
\hline $\begin{array}{l}\text { t-value } \\
\text { (paired sample test) }\end{array}$ & & -6.138 & & -6.642 \\
\hline df & & 124 & & 124 \\
\hline $\begin{array}{l}\text { Significance level } \\
\text { (2-tailed) }\end{array}$ & & $<0.0001$ & & $<0.0001$ \\
\hline
\end{tabular}

* Of a total number of 125 farmers 
After the adoption of improved technology, the mean stocking was 3644.7 fingerlings and the mean output (harvest) $5828 \mathrm{~kg}$. Here, the output: input ratio was $1.60 \mathrm{~kg}$ per fish fingerling. This indicates that there is an appreciable increase in the output: input ratio (nearly 2 -fold increase; $0.77 \mathrm{~kg}$ per fish fingerling after adoption of improved fish technology. The implication is that the use and adoption of improved technology has positive influence on production output of fish farmers in the study area. This result is consistent with the finding of Ashaolu et al. (2006) who observed that fish farming is profitable.

\subsection{Constraints faced by fish farmers in using improved fish production technology}

Of the perceived constraints to adopt improved fish production technology (Table 6), inadequate capital was the most severe (88.0\%), which confirmed the findings of Adefalu et al. (2013) in Kwara State and of Issa et al. (2014) in Kaduna State.

Table 6. Constraints faced by fish farmers in using improved fish production technology (Source: field survey, 2015)

\begin{tabular}{lccc}
\hline Perceived Constraints & Frequency & Percentage & $\begin{array}{c}\text { Percentage } \\
\text { Rank }\end{array}$ \\
& & & 1 \\
\hline Inadequate capital & 110 & 88.0 & 2 \\
High cost of feed & 99 & 79.2 & 3 \\
High cost of fingerlings & 89 & 71.2 & 4 \\
Poor marketing structure & 78 & 62.4 & 5 \\
High cost of land & 75 & 60.0 & 6 \\
Lack of technical skill & 73 & 58.4 & 7 \\
Poor extension service & 71 & 56.8 & 7 \\
Water scarcity & 71 & 56.8 & 9 \\
Poor managerial skill & 64 & 51.2 & 10 \\
Poor transport facility & 61 & 48.8 & 10 \\
Disease outbreak & 61 & 48.8 & 12 \\
Lack of commercial hatchery & 58 & 46.4 & 13 \\
Illiteracy & 46 & 36.8 & \\
\hline
\end{tabular}

About $79.2 \%$ respondents felt that high cost of feed was a major constraint. Nwachukwu and Onuegbu (2007) had noted that feeding was always a problem because farmers were not always able to afford the cost of the feed. This could be due to sudden change in the price of feed as a result of inflation. 
Due to the low quality of locally produced fish feed, farmers are often dependent on imported feed, which are more expensive and may be scarce because of import policies. Olaoye et al. (2013) also found similar results among catfish farmers in Oyo state, Nigeria. High cost of fingerlings and poor market structure are also other major constraints faced by catfish farmers in the study area (Table 6).

3.7 Pearson Correlation Analysis of Socio-economic characteristics of respondents and effects of improved fish technology on fish production

Increase of profit/income via higher yield/harvest due to improved technology had significant positive correlation with age $(\mathrm{r}=0.230 ; \mathrm{p}<0.01)$, gender $(\mathrm{r}=0.214 ; \mathrm{p}<0.05)$, experience $(\mathrm{r}=0.194 ; \mathrm{p}<0.05)$, and income $(\mathrm{r}=0.228$; $\mathrm{p}<0.05$ ) (Table 7). These are in agreement with findings of Langy and Mekura (2005) who reported that older farmers have higher accumulated capital, more contacts with extension workers, better preferred by credit institutions and larger family size, all of which may make them more prepared to adopt technology more than younger ones, but not in agreement with Ume, et al. (2009), who suggested that older farmers are less amendable to change and hence reluctant to adopt new technologies. According to Langy and Mekura (2005), experience of farmers is generally relevant to adopt new technology through interaction with their neighbours and the outside world.

Table 7. Results of correlation between socio-economic characteristics of respondents and effects of improved fish technology on fish production

\begin{tabular}{llc}
\hline Variables & r-value & $\begin{array}{c}\text { Significant level. } \\
\text { (2-tailed) }\end{array}$ \\
\hline Age & $0.230^{* *}$ & 0.010 \\
Gender & $0.214^{*}$ & 0.017 \\
Marital Status & 0.159 & 0.077 \\
Educational Status & 0.169 & 0.059 \\
Fish farming Experience & $0.194^{*}$ & 0.030 \\
Fish size & 0.063 & 0.488 \\
Income & $0.228^{*}$ & 0.011 \\
\hline
\end{tabular}

**Correlation is significant at the 0.01 level (2-tailed)

*Correlation is significant at the 0.05 level (2-tailed)

\section{Conclusion}

Based on findings in the study, it was concluded that use of fish improved technology had positively influenced fish production output of fish farmers in the study area. Secondly, fish farmers had high perception that farmers' uses/adoption of improved technology increased profit/ income via higher yield/harvest. Thirdly, the major determinants of farmers output through improved technology were: age, marital status, educational status, fish farmers 
experience, fish size, and income of respondents. However, inadequate capital and high cost of feeds were found to be the major factors affecting the output of fish farming in the study area.

Based on the findings of this study, following recommendations are proposed. Associations of Catfish Farmers in the study area should focus its training, workshops and seminars more on how members could have easy access to land, feeds at affordable rate and sources of fund at minimal interest rate. The extension agent to farmer coverage needs to be improved upon, so that regular and prompt visits could be made to fish farmers in order to intensify the adoption of improved fish technology. Government should encourage the fish farmers by providing for them credit facilities at minimal interest rate, subsidized costs of improved fish feeds and fingerlings, and other improved fish production technology, thereby increasing their productivity. Fish farming in the area is male dominated. Females need to be encouraged to participate in fish farming in the area as a means of augmenting their income and improving their standard of living.

\section{References}

Abiona BG, Fakoya EO, Apantaku SO, Alegbeleye WO, Ajayi MT, Obasa SO, Arowolo K. 2012. Assessment of Farmer's Technologies on Integrated Fish Farming and Non Integrated Fish Farming in Ogun State, Nigeria. Global Journal of Science Frontier Research Agriculture \& Biology 12 (2): 1-8.

Adefalu LL, Aderinoye-Abdulwahab SA, Bello OG, Olorunfemi OD, Oba SA. 2013. Information Needs of Fish Farmers in Ilorin Metropolis, Kwara State Nigeria. Nigerian Journal of Agriculture, Food and Environment 9(2): 1-5.

Agbamu JU. 2006. Essentials of Agricultural Communication in Nigeria. Malthouse Ltd. pp. $65-73$.

Ashaolu OF, Akinyemi AA, Nzekwe LSO. 2006. Economic Viability of homestead Fish Production in Abeokuta Metropolis of Ogun State Nigeria. Asset Series A 6(2): 209-220.

Chioma GN, Adebayo Z. 2012. Constraints to Fish Farming Among Women in Nigeria. Advances in Environmental Biology 6(4): 1421-1425.

Delgado CL, Wada N, Rosegrant MW, Meijer S, Ahmed M. 2003. The Future of Fish: Issues and Trends to 2020. International Food Policy Research Institute, Washington DC, USA, pp 19: 1-22.

Ezedinma CI, Oti NN. 2001. Socio-economic issues in the development of cassava processing technology in Nigeria. Journal of Sustainable Agriculture and the Environment 3(1):120126.

Ekong E.E. 2003. An introduction to rural sociology (2nd edition). Uyo. Nigeria dove educational publishers. Pp 259-285.

FAO. 2004. The state of world fisheries and aquaculture. 2003. Rome: FAO Fisheries.

FAO. 2006. Fisheries management in the Federal Republic of Nigeria. www.fao.org/fi/fcp/en/NGA/ body, retrieved on April 13, 2015.

Fakoya EO. 2000. Farmers Use of Sustainable Land Management Practices in Ondo State, Nigeria. Unpublished PhD. Thesis, Department of Agricultural Extension and Rural Development, University of Ibadan. pp 160.

Fasakin EA. 2008. Fish as Food: Yesterday, Today and Forever. Inaugural Lecture Series 48; The Federal University of Technology, Akure. pp 6-7.

FDF. 2005. Report of Presidential Committee on Fisheries and Aquaculture Development, Volume One: Consolidated report. September, 2005. 63pp. 
Ideba EE, Otu WI, Essien AA, Iniobong EO, Ekaette SU. 2013. Economic Analysis of Fish Farming in Calabar, Cross River State, Nigeria. Greener Journal of Agricultural Sciences 3(7): 542-549.

Ike SE, Onyishi GC, Ukwuaba GC, Oluason VA. 2009. Farm evaluation of profitability and farmer's acceptability of Bambara Nut waste as major protein supplement in fish diet in Heterobranchus and Tilapia spp polyculture. Proceedings of National Farming System Research Network held at Umudike. pp. 127-129.

Issa FO, Abdulazeez MO, Kezi DM, Dare JS, Umar R. 2014. Profitability analysis of small scale catfish farming in Kaduna State Nigeria, Journal of Agricultural Extension and Rural Development 6(8): 267-273.

KWADP. 2000. Kwara State Agricultural Development Project Annual Report, pp. 3-7.

Lakra WS, Ayyappans AF. 2003. Recent Advances on Biotechnology Applications to Aquaculture. Central Institute of Fisheries Education, (Indian Council of Agricultural Research), Versova, Mumbai.

Langy A, Mekura M. 2005. Modelling agricultural technology adoption using the software STAT. A paper presented at a training course organised by CIMMUTALP for its NARS partners in Southern Africa on econometric application of modelling technologies.

Nwachukwu I, Onuegbu R. 2007. Adoption of Aquaculture Technology by Fish Farmers in Imo State of Nigeria. The Journal of Technology Studies 33(1): 57-64.

Ofuoku AN, Emah GN, Itedjere BE. 2008. Information utilization among rural fish farmers in Central Agricultural Zone of Delta State Nigeria. World Journal of Agricultural Science 4 (5): $558-564$.

Oladoja M A, Adedoyin SE, Adeokun OA. 2008. Training needs of fisher folks on fishing technologies. Journal of Food Agriculture and Environment Science and Technology 6(1): 95-198.

Ogunwale B. 2000. Communication channels for information dissemination on poverty alleviation among small scale farmers in Oyo State. Paper presented at AESON Conference, UI Ibadan, Nigeria.

Oladele OI, Sakagami J, Toriyama K. 2006. Research-Extension-Farmer linkage System in Southwestern Nigeria, Journal of Food Agriculture and Environment 4(1): 197-200.

Olaoye OJ. 2010. Dynamics of the Adoption Process of Improved Fisheries Technologies in Lagos and Ogun States Nigeria. Ph. D thesis, Federal University of Agriculture, Abeokuta, Ogun State, Nigeria. pp. 337.

Olaoye OJ, Ashley-Dejo SS, Fakoya EO, Ikeweinwe NB, Alegbeleye WO, Ashaolu FO, Adelaja OA. 2013. Assessment of Socio-Economic Analysis of Fish Farming in Oyo State, Nigeria. Global Journal of Science Frontier Research Agriculture and Veterinary 13(9): 45-55.

Okunlola JO. 2010. Factors influencing Adoption of Rubber Based Technologies among Small Holder Farmers in Delta state Nigeria. Journal of Food Agriculture and Environment 8(2): 391-394.

Okunlola, JO, Oludare AO, Akinwalere BO. 2011. Adoption of new technologies by fish farmers in Akure, Ondo state Nigeria. Journal of Agricultural Technology 7(6): 1539-1548.

Raufu MO, Adepoju MO, Salau AS, Adebiyi OA. 2009. Determinants of yield performance in small scale fish farming in Alimosho Local Government Area of Lagos state. International Journal of Agricultural Economics and Rural Development 2(1): 9-14.

Ruma YA. 2008. Fish production systems. A workshop held at Enugu State University, fisheries project.

Ume SI, Uloh VE, Okoronkwo MO. 2009. Adoption of improved rice production technologies by farmers in Anambra State. Ebonyi technology and vocational education journal 3(1): 17. 